This is the authors' post-print PDF version

of the paper 'Women, pigs, God and evolution: Social and economic change among Kubo people of Papua New Guinea' published in Oceania.

Citation details for the published version are:

Minnegal, M. and P.D. Dwyer (1997) Women, pigs, God and evolution: Social and economic change among Kubo people of Papua New Guinea. Oceania 68: 47-60.

\title{
WOMEN, PIGS, GOD AND EVOLUTION: SOCIAL AND ECONOMIC CHANGE AMONG KUBO PEOPLE OF PAPUA NEW GUINEA
}

\author{
Monica Minnegal ${ }^{1}$ and Peter D. Dwyer ${ }^{2}$
}

1. Department of Anthropology and Sociology, University of Queensland, Brisbane, Qld 4072

2. Department of Zoology, University of Queensland, Brisbane, Qld 4072

\begin{abstract}
This paper depicts connections and interactions between several apparently disparate themes of change observed in recent years at a village in the interior lowlands of Western Province, Papua New Guinea. Changes in patterns of association between men and women can be traced, in the first instance, to altered management practices necessitated by intensified pig production. That intensification, in turn, reflects the growing importance of money in the local economy, a shift which, through its predication on recognising the commensurability of differences, has ramifications far beyond the economics of pig production. An earlier emphasis on equivalence in exchanges has been replaced by a recognition of substitutability, with a consequent reification of categories at the expense of individuality. This trend has been reinforced by the influence of a new Christian cult that, in emphasising the distinction between men and women, has reified gender categories as a basis for structuring social action. The declining association between men and women which emerged as an adaptive response to changing economic realities has thus become incorporated as a structural transformation in Kubo social life.
\end{abstract}




\section{The Woman's Shelter}

Between October and December 1995 a married woman built a shelter behind her family's house at the village of Gwaimasi on the west bank of the Strickland River. Though rough in construction, the shelter was quite large. The floor was of beaten earth, the hearth substantial and along one side was a rack where firewood was stored. There were no walls. The woman did most of the work herself, sometimes, on moonlit nights, sitting for hours and singing quietly as she thatched the roof. It was only in the final phase of the project that she sought help from her husband to complete the awkward task of closing the ridge line of the roof with pre-prepared sheets of sago thatch. Until this time neither her husband nor anyone else had offered assistance.

Through these months of building, and afterwards, the woman spent an increasing amount of time at her shelter. She would be there at first light each morning, sitting at the hearth, turning bananas on the fire and scraping and peeling others that she had already cooked. Her husband and two children sat apart at the family hearth in another house where they prepared and ate breakfast. The forty or fifty bananas that she cooked each morning were not for her family, they were for pigs that were in her care. And for another hour or two in the late afternoon, or sometimes well into the night if she had been delayed at other tasks, she would again be at her shelter cooking for the pigs while her husband and children relaxed after the day's work, gossiped with other village residents and exchanged news with the latest visitors.

The woman liked her shelter. It became a place of her own, to keep possessions or chat with other women and a retreat where she escaped from tensions that were emerging in her marriage. But at that shelter she was isolated from her family for several hours each day. Through ten years of visiting Kubo people we had not seen anything analogous to this woman's shelter. Its construction and use were symptomatic of more general changes at Gwaimasi, changes to the ways in which women and men organized their space and time, and the impacts these had on gender relations.

\section{INTRODUCTION}

Change in form is never unidimensional. Rather it entails simultaneous shifts along multiple dimensions that, whether ecological, social or ideological, are themselves necessarily connected. These connections may either elicit or inhibit further change.

But nor, it should be understood, is change itself a unitary phenomenon. On the one hand, there are potentially reversible context-dependent changes that are entailed in the reproduction of form. Such changes are evidenced by quantitative shifts in the expression of particular variables without substantive alterations to relationships between those variables. On the other hand, relationships between variables may alter to elicit qualitative changes that, if viable, are potentially irreversible. In the first case, change is manifest as an alteration to statistical properties of an ensemble of variant types. In the second case, change is manifest as an alteration to the structure of the ensemble as a whole (Levins and Lewontin 1985: Chapter 3). We label these categories of change 'adaptation' and 'transformation', respectively ${ }^{1}$. 
This paper explores social and economic changes that have occurred among Kubo people of the lowland interior of Papua New Guinea in the last ten years. The themes identified concern pig husbandry, gender and exchange relations, and cosmological understandings. The context within which change occurred was, at base, modernity which has entailed shifts in settlement dynamics, monetisation and an accommodation to Christianity. The primary aim of our account is to depict connections and interactions between several seemingly disparate themes of change. But, further, we seek to identify components of change that qualify, respectively, as adaptation and transformation; this is necessary, we assert, to move toward a theoretical understanding of the causes and consequences of change.

\section{BACKGROUND}

Kubo comprise a population of about 450 people living as widely dispersed communities in an area north of Nomad in the Western Province of Papua New Guinea. Their territory is contiguous with those of Pare, Konai, Febi, Bedamuni and Samo. The cultural affinities of the people are with the Strickland-Bosavi complex (Knauft 1985) and the Kubo language, which Shaw (1986) treated as a dialect of Samo, is included within the Bosavi language family. Shaw's $(1982,1990)$ account of Samo and Knauft's (1987) account of Gebusi nicely capture much of the formality of social structure, the cosmology and the exuberant ethos of Kubo.

The central features of Kubo social structure are patrilineal clans linked by shared matrilateral ties, exogamous marriages with sister exchange as ideal and, until very recently, male initiation. Clans own particular areas of land and the wild resources located there but, traditionally, residential arrangements were relatively fluid and primary settlements of mixed clan membership relocated every three or four years. Kubo are hunterhorticulturalists who depend on bananas and other crops from small gardens, sago from wild and planted Metroxylon palms, fishing and hunting (Dwyer and Minnegal 1991, 1992a, 1994; Minnegal and Dwyer 1995). They keep domestic pigs, numerous dogs and, since 1991, chickens and a few cassowaries (Dwyer and Minnegal 1992b). A government presence at Nomad, which is outside Kubo territory, since the mid to late 1960s and the subsequent arrival of missionaries has increasingly resulted in abandonment of interclan and interlanguage-group raiding and in the appearance of larger and more permanent communities. These changes emerged first in the southeast of Kubo territory but had little overt influence to the north or northwest until the early 1980s.

Gwaimasi village, at an altitude of $80 \mathrm{~m}$ above sea level, is located on the western bank of the Strickland River $48 \mathrm{~km}$ NNW from Nomad $\left(5^{\circ} 54^{\prime} \mathrm{S}, 142^{\circ} 6^{\prime} \mathrm{E}\right)$. The village was established in 1986 by a group of 25 Kubo-speaking people who use an area of about $50 \mathrm{~km}^{2}$ to satisfy subsistence needs. Two days' walk to the southeast there is a mission station at Suabi, within Kubo territory, that was established in 1984 and one day's walk to the northwest there is another mission station, at Dahamo within Konai territory, established in 1987. Primary schools opened at Suabi in 1988 and Dahamo in 1989 and since then, at both stations, government-sponsored medical aid-posts have usually been staffed.

By 1991 the population at Gwaimasi had increased to 42 people as a result of fusion with a nearby mixed Konai-Kubo group but, in response to emerging tensions, all the later arrivals had departed by 1994. In 1995, 31 people were residents of Gwaimasi though one family of seven lived at Dahamo throughout the school year. Although the population has 
remained small Gwaimasi qualifies as one of only three Kubo communities that have remained at the same location for at least a decade. We visited the area in January 1986 before the village was established, lived at Gwaimasi for 15 months from August 1986, for two months late in 1991 and again in 1994-95, and for five months from August 1995. Comparisons of observations from our two longer visits are central to the present paper. Quantitative data concerning pigs and people's movements were obtained by the methods reported in Dwyer (1993) and Dwyer and Minnegal (1993).

\section{WOMEN AND MEN: CHANGING PATTERNS OF ASSOCIATION}

In 1986-87 the strength of the association between women and their husbands was remarkable (Table 1). Each nuclear family - parents with unmarried children - had its own house at the village and cooked, slept and hosted visitors as a unit. Through that period, during times when both wife and husband were resident at the village they spent, on average, 74 percent of days together, working at related tasks in the same general area. Couples planted or weeded a garden together, a husband might care for an infant while his wife processed sago nearby, or she might wait at the base of a tree to retrieve animals that her husband, sitting in a birdhide above, shot with bow and arrows. Again, if a married man left the village to stay one or more nights at a bush house within the local subsistence area then, on average, his wife accompanied him 85 percent of the time. In 1986-87, then, husbands and wives at Gwaimasi worked and travelled together as a team. In a community where everyone was bonded through daily sharing of both raw and cooked plant and animal foods the family was always highly visible (Dwyer and Minnegal 1992a).

Table 1: Association between women and men at Gwaimasi

(Sample sizes in parentheses)

\begin{tabular}{ccccc}
\hline \multirow{2}{*}{$\begin{array}{c}\text { Married } \\
\text { woman }\end{array}$} & $\begin{array}{l}\text { Days when husband and wife worked } \\
\text { together as percentage of days when } \\
\text { both were based at the village }\end{array}$ & $\begin{array}{l}\text { Days when wife accompanied husband } \\
\text { as percentage of days when husband } \\
\text { was based in bush in local area }\end{array}$ \\
\cline { 2 - 5 } & $1986-87$ & 1995 & $1986-87$ & 1995 \\
\hline 1 & $83[245]$ & $50[103]$ & $95[88]$ & $40[5]$ \\
2 & $69[213]$ & $33[93]$ & $67[62]$ & $6[16]$ \\
3 & $77[191]$ & $64[76]$ & $84[59]$ & $82[34]$ \\
4 & $79[179]$ & $52[82]$ & $90[50]$ & $18[28]$ \\
5 & $78[251]$ & - & $91[46]$ & - \\
6 & $60[156]$ & - & $83[127]$ & - \\
7 & $86[30]$ & - & nil $[3]$ & - \\
8 & - & $56[63]$ & - & $44[32]$ \\
9 & - & $43[91]$ & - & $31[29]$ \\
10 & - & $84[87]$ & - & $100[1]$ \\
\hline Average $^{*}$ & 74 & 50 & 85 & 37 \\
\hline
\end{tabular}

1986-87 averages exclude woman 7 and her husband; $1995-96$ averages exclude woman 10; see note 1 . 
Nine years later families still maintained separate houses within the village but patterns of association between women and their husbands had changed (Table 1). In 1995, when both were resident at the village, they spent on average only 50 percent of days together and women accompanied their husbands on an average of only 37 percent of the days that the latter were based at bush houses ${ }^{2}$. Four of the seven couples in 1995 were already married during the earlier survey, but the decline in association was not simply an artefact of aging relationships; in neither period was association correlated with age of individuals or marriages. There was, of course, variation in the behaviour of different couples and this was more evident in the later than in the earlier survey period. But the magnitude of the shift in average levels of association and the consistency in the direction of those shifts reflects a general decline across 10 years in the strength of association between women and their husbands.

In 1995 men spent on average approximately the same amount of time at bush houses as they had in 1986-87 but women spent less than half as much time in the bush (Table 2). In fact, women now usually only accompanied their husbands on overnight or extended trips away from the village when there was no one else to go; other adults accompanied the couple on only $40 \%$ of absences in 1995, whereas others were present on $69 \%$ of occasions during the earlier survey. In 1995, to a far greater extent than in 1986-87, the mobility of women was curtailed and the primary reasons for this concerned changes in both the numbers of pigs in care and the ways in which those pigs were managed.

Table 2: Mobility of married women at Gwaimasi (Sample sizes in parentheses)

\begin{tabular}{clc}
\hline $\begin{array}{l}\text { Married } \\
\text { woman }\end{array}$ & \multicolumn{2}{c}{$\begin{array}{c}\text { Nights spent away from village } \\
\text { as percentage of all nights in } \\
\text { local subsistence area }\end{array}$} \\
\cline { 2 - 3 } & $1986-87$ & 1995 \\
\hline 1 & $25[363]$ & $2[127]$ \\
3 & $12[357]$ & $1[125]$ \\
4 & $20[259]$ & $23[122]$ \\
5 & $21[234]$ & $5[113]$ \\
6 & $18[333]$ & - \\
7 & $39[347]$ & - \\
8 & nil [32] & - \\
9 & - & $15[92]$ \\
10 & - & $7[127]$ \\
\hline Average for wives & & $1[90]$ \\
Average for husbands & - & 9 \\
\hline * & 22 & 22 \\
\hline woman 10 and her husband. $^{*}$ & 25 & \\
\hline
\end{tabular}




\section{WOMEN, PIGS AND WORK}

In 1986-87 people at Gwaimasi cared for between seven and 13 domestic pigs (0.270.54 pigs per person), with an average in any one month of 9.5 pigs or 0.38 pigs per person. Nine years later the domestic pig population varied through a five month survey from 21 to 30 (0.74-1.04 pigs per person) with an average in any one month of 23.8 pigs or 0.88 per person. This increase in the number of pigs was accompanied by, and indeed necessitated, a change in the organization of pig production.

Among Kubo it is women who act as carers to pigs and, at least in 1986-87, management of domestic pigs entailed bonding of particular pigs to particular carers such that, though older pigs might range widely, they always responded to a summons from their carer (Dwyer 1993). Piglets were usually taken into care two to four weeks after birth and for the next few weeks were carried, petted, spoken to and trained to accept a lead. They travelled wherever their carer went both within and beyond the local area. After an age of about five months domestic pigs were allowed to forage alone through the day but were brought home each night, tied up, stroked and fed. Their daytime foraging places varied depending on the location of the woman's activities. This pattern of daily interaction between a pig and its carer continued until the pig was nearly 18 months old. It was only after this time that pigs were released to live alone in the bush, usually in the backswamps, several kilometres from the village, where sago palms were abundant and could be felled to provide a surfeit of food. Even now, however, carers regularly visited their free foraging pigs reinforcing the bond that had been established through the first year and a half ${ }^{3}$.

With a larger population of domestic pigs in 1995 earlier management procedures could not be sustained. With more pigs a woman could not give each pig the attention that had formerly been possible. Village-based pigs were more often left tethered the village when their carers departed to work at gardens or process sago through the day. Similarly, older bush-based pigs were visited less often. The outcome was that the bond established between a woman and each pig in her care was not as strong as before. At Gwaimasi this shift was reflected in the rate at which pigs were lost. In 1986-87 people spoke of occasions when domestic pigs had been lost but, in fact, this did not happen to any of the 19 pigs that were in care at some stage during those 15 months. By contrast nine of 43 different pigs, including animals from a few months to a few years in age, were lost between December 1994 and the end of December 1995. Other pigs went missing for several days at a time, with women sometimes spending the better part of three or four days searching before the miscreant was recovered.

To reduce the risk of losing pigs that were not strongly bonded, women kept them at the village more often. In 1995 pigs of $60 \mathrm{~kg}$ or more were kept at the village where previously pigs heavier than $40 \mathrm{~kg}$ were unlikely to be at the village unless they had been brought in from the bush to be slaughtered. Thus, while the number of domestic pigs in care had doubled between the two survey periods the number that were village-based had nearly trebled, and the average weight of village-based pigs had increased from $17.9 \mathrm{~kg}$ to $28.5 \mathrm{~kg}$. This increase in the biomass of village-based pigs together with the reduced likelihood that pigs were routinely taken out of the village to forage led to an enormous increase in the work loads of women. Our estimates are that in 1995 relative to 1986-87 the biomass of village-based pigs had increased by a factor of 3.6 and that the amount of food provided to each village-based pig had doubled. Thus, the effort required to fodder village-based pigs had, at a minimum, quadrupled over a nine year period but the number of women who 
contributed to this work had not changed. The increased labour entailed in foddering pigs, together with the heightened risk that pigs taken to the bush might be lost, had the result that women were less willing to ask others to care for their pigs during an absence of a few days. And those other women, understandably, were less likely to offer such assistance ${ }^{4}$.

An increase in the number of pigs, an increase in the proportion of those pigs kept at the village and, particularly, an increase in the work associated with foddering those pigs acted to restrict the mobility of women who cared for pigs. Indeed, variation in mobility between married women (see Table 2) reflected this constraint; in 1995 the two women who spent proportionately most nights away from the village were the only married women who did not act as primary carers to any village-based pigs through most of the survey period. These two women also spent more time with their husbands than did other women though their association with husbands was still less than was typical in 1986-87 (see Women $3 \& 8$, Table 1). The reason for this decline in association despite having no pigs in care was straightforward. Men who could not take their wives to the bush usually went with other men instead; single sex tasks groups were emerging by default. Wives without pigs were less likely to be invited to accompany their husbands because wives with pigs were not free to accompany their husbands. The men went to the bush together; the women were left at the village together ${ }^{5}$.

\section{THE ALIENATION OF WOMEN'S LABOUR}

In 1986-87 the bond established between a woman and each of the pigs in her care was such that only that woman could handle these pigs with confidence (Dwyer 1993). When a primary carer did leave a village-based pig in the temporary care of another woman then it was usual that the pig was kept tethered for the duration of the primary carer's absence. And if a pig broke tether or returned unaccompanied to the village everyone scattered, calling to the pig's carer to come and claim the animal. People were extremely cautious about approaching pigs that were not in their care. The difficulty and, indeed, danger inherent in handling a pig raised by someone else gave a woman tremendous control over the disposal of pigs in her care, control over not only those she herself owned but also those looked after for male relatives. Since only she could safely bring in the pig for slaughter no exchange could proceed without her active cooperation. And, for her labour, she was entitled to half the pork that was received in exchange for her pig, to distribute as she saw fit.

But by 1995 the strength and specificity of the bond between a woman and her pigs had lessened. Most pigs were bound more to the village than to a particular person and were no longer perceived as a serious threat to others. In sharp contrast to the behaviour seen nine years earlier, there were several pigs of $60 \mathrm{~kg}$ or more that often wandered free within the village domain and could be approached and groomed by men and children. With others now able to handle her pigs, the active cooperation of the primary carer at the time of their disposal was no longer essential. It was no longer necessary that this particular woman brought in and tethered the pig at a stake, then stood beside the pig to calm and keep it under control as it was killed. It was, in other words, no longer a necessary part of the performance that the woman publicly demonstrate both the effort she had committed to production and her approval of the use to which the outcome of that effort was now being put. 
With pigs less strongly bonded to people, and the consequent increased probability that a product of considerable labour might be lost to the bush, the attributes which Kubo looked for in pigs had also changed. The risk of loss put a premium on pigs with a more 'domestic' predisposition, pigs that were unlikely to go wild even with minimal bonding. In 1986-87 all pigs at Gwaimasi were the progeny of wild boars, and often of wild sows; the potential for selection of particular attributes would have been limited (cf. Dwyer in press). By 1995, however, people at Gwaimasi occasionally obtained piglets from their Febi neighbours to the north. These animals, which Kubo called $o$ susu, had in fact come from the Highlands, usually via Duna people and were from stock that had been bred in captivity, and crossed with breeds of European origin, for many generations. They were unlike local pigs, with shorter legs and snout, large ears and a curled tail. They grew more rapidly and, with appropriate provisioning and handling, became fatter than the pigs of local origin. Foddering of o susu was labour intensive because these pigs required sweet potato which was locally scarce rather than bananas which were abundant, but the effort was considered worthwhile - though they were acquired when older than the age at which local pigs were taken into care, o susu were extremely tame. These pigs, therefore, were highly valued and people were enthusiastic about obtaining more. But this has some unforseen implications.

In 1986-87 the recruitment of pigs to village herds and the ownership of those pigs was primarily under the control of women. When a domestic sow had given birth in the bush and the piglets were old enough to be captured and taken into care it was the sow's carer who invited particular individuals to be members of the group that would capture the piglets. Those who caught a piglet held rights of ownership to that piglet. And women too were more likely than men to capture piglets born to wild sows and take them into care. But the desire to obtain o susu from the north shifted responsibilities and opportunities for procurement of pigs from women to men. It was the latter who had most access to the money needed to purchase those pigs and the freedom to travel to the north in search of them. Increasingly, recruitment of pigs to the village population entailed arrangements between men of different language groups even though women continued to be charged with the responsibility for rearing those pigs.

The loosening of bonds between pig and caretaker that has occurred at Gwaimasi has the potential to reduce or remove women's control over both the original procurement and the final disposal of domestic pigs. Thus the scene has been set for the alienation of women from the objects of their labour. And it is precisely this process of alienation that anthropologists have seen as crucial to both the construction of social inequalities (Kelly 1993) and the evolution of the intensive systems of surplus production found in the New Guinea highlands (Modjeska 1982; Strathern 1982, Godelier and Strathern 1991; cf. Feil 1987; Kelly 1988).

"WHAT ARE ALL THESE PIGS FOR?"

[A refrain from field notes, 1995]

In 15 months during 1986-87 people at Gwaimasi killed eight of 19 domestic pigs that had been reared locally and three others that had been brought to the village by visitors. Thus, they killed the equivalent of almost half the number of pigs held in care at any time during that survey period. Six of these pigs were killed at an intercommunity feast that asserted the viability of Gwaimasi as a community, three were killed to fulfil the needs of curing rituals and an associated seance and two because the animals had become 
troublesome. But in the 12 months of 1995 only three of 43 pigs were killed and none of these was eaten at the village. One of the three was butchered and distributed at a feast held by another Kubo community, one was sold to people of a neighbouring language group who required pork to satisfy an overdue payment of bride-wealth and the third was sold to school teachers at a mission station one day's walk from Gwaimasi. Only in the first case was there an expectation of a future exchange of pork. No domestic pigs were killed at a large intercommunity feast held at Gwaimasi in December 1995 though this was larger than the event witnessed in 1986-87; there had initially been much talk of doing so, but wild pig was provided instead. The feast celebrated completion of a major communal building project - a new church. In many ways, churches now serve a role among Kubo as community foci analogous to that of longhouses in the past; certainly the building of both kinds of structures necessitates a degree of longterm coordination that is not entailed in other activities. In earlier years feasts held to mark completion of longhouses usually included domestic pork. Indeed, 10 pigs had been killed when Gwaimasi's longhouse had been opened in 1986, before our first survey commenced. (By 1991 that longhouse had collapsed and been demolished; it was not replaced.) Less than ten years later, no one was prepared to contribute a pig to an analogous event.

At Gwaimasi, therefore, an extraordinary increase in effort devoted to the production of domestic pigs was paralleled by a decrease in the consumption of domestic pork. This was not of consequence in terms of access to dietary protein because much meat from wild animals, particularly wild pigs, continued to be available (cf. Dwyer and Minnegal $1991)^{6}$. But it does make the increased production of pigs more puzzling. The numbers of domestic pigs at Gwaimasi in 1986-87 were already high compared to values usually reported in lowland communities (Dwyer 1993); by 1995 the per-capita size of the local domestic pig population was well within the range of values reported from the much larger and more complex societies of highlands New Guinea (cf. Kelly 1988). These latter are societies where competitive exchange of pigs is a major preoccupation, but analogous exchanges are clearly not motivating production of pigs at Gwaimasi. In fact, differences in the number of pigs per person at Gwaimasi during the 1986-87 and 1995 surveys are similar to those reported for Tsembaga Maring where numbers shifted across years from 0.3 to 0.86 per person (Rappaport 1968). Among Tsembaga, however, variation in the population size of domestic pigs was party to a relatively long-term ritual cycle. The change in pig numbers at Gwaimasi was not part of a comparable cycle of replenishment and ceremonial disposal; rather, it reflected shifting perceptions concerning the use-value of pigs.

Our friend Tufa, watching with us one afternoon in 1995 as a woman struggled to round up her recalcitrant pig, commented "keeping pigs is hard work, too much work" but then added, after a moment's thought, "pigs are good to eat ... and good to sell". It is in the last part of Tufa's statement that the explanation for both increased production and decreased consumption of domestic pigs at Gwaimasi is to be found. By 1995 people were motivated to keep pigs because of the potential they afforded - a potential that, in fact, was unlikely to be realised - for access to money.

There are few sources of money available to Kubo people. The area has been visited occasionally by mining exploration teams, by anthropologists and, since the mid 1980s, on a more regular basis by missionaries, teachers and aidpost orderlies. These outsiders, particularly in the first two categories, have been significant sources of money with mining companies visiting for periods of two to three months three times in the past 10 years, 
employing every able-bodied male in the local area to cut seismic lines and then vanishing, and with the authors of this paper visiting for four periods of from two to 15 months through the same decade. The injections of cash that have resulted from these visits have facilitated changes to the local economy such that monetary payments are now expected when a man elopes with a woman or an individual is hired to ensorcell an unknown sorcerer. They have also raised expectations concerning opportunities for obtaining items such as radios, shotguns and outboard motors. But, of course, miners and anthropologists have their own agendas; their arrival with money constitutes intermittent events that are essentially beyond local control. Where the source of money appears more permanent, as with missionaries, teachers and aidpost orderlies, the amounts received are generally insufficient to meet desired objectives. From time to time, however, employees of mining companies or government have paid seemingly large amounts of money for domestic pigs and these purchases have engendered the perception that by raising pigs people might themselves take control over the production of money.

The emergent belief that domestic pigs might be used to acquire money means that pigs have become both differently and more valued, sufficiently valued that they are worthy of the investment of more labour than before and even of the investment of money to purchase small pigs of desired quality. And sufficiently valuable, in fact, that owners are disinclined to dispose of them in traditional ways and, thereby, lose a potential future opportunity to sell them for money ${ }^{7}$.

\section{THE COMMENSURABILITY OF DIFFERENCE}

In reality, among Kubo, there are few opportunities for the sale of pigs and, because there is not much money circulating in the local community, some sales are never finalized with individuals who provided pigs still waiting for payment several years later. But, whether the imagined potential is realised or not, the recognition that pigs might be sold represents a major conceptual shift for Kubo, one with ramifications that go far beyond the economics of pig production. Monetary exchanges are predicated on a recognition of the commensurability of very different categories of objects, a concept that challenges the basis of Kubo sociality.

Traditionally, among Kubo, a pig could be exchanged only for another pig. Pigs were sometimes killed without material exchange, for curing rituals, as a mortuary payment, or as compensation for the services of a spirit medium, but such episodes did, in fact, entail exchange. As is common in New Guinea (Rubel and Rosman 1978), Kubo people do not eat pigs that they themselves own or have raised or, indeed, that are owned or have been raised by siblings or spouses. To do so would be anathema; the carer has put so much of herself into these animals that they have come to partake of her (and her lineage) essence. Thus the sacrifice of a pig in curing dances and mortuary payments could be seen as an exchange of essence for essence, the essence embodied in the pig substituted for that of the person focal to the event. As with the material exchange of pigs, the transaction is one of like for like.

Kubo construct the exchange of pigs in terms of a desire to eat pork. Two individuals, having agreed that they wish to eat pork, will avoid the constraint on eating their own pig by arranging to swap. In fact, of course, these arrangements negotiate and reinforce relationships between the parties; most reciprocal exchanges occurred between individuals who had made an arrangement several years earlier, when the pigs were first taken into 
care. (Both women and men could be party to these arrangements.) When the time comes for exchange, the two pigs are brought together and killed at the same time, the meat from each handed to the other's owner for distribution. The exchange is not merely immediate, but expected to be finely balanced with regard to size, sex and colour of the animals. Such balance is not about cancelling debts, and thus maintaining independence; interdependence is taken for granted. Rather, balance underwrites the equivalence of the parties to the exchange, as mutual donors and recipients (Gregory 1982). Thus pig exchanges are imbued with an emphasis on the absoluteness of difference; there is no way that a black pig can be made commensurate to a white one, a male pig to a female one ${ }^{8}$.

Kubo sociality, like that of other societies on the fringe of the New Guinea highlands (e.g., Godelier 1986; Jorgensen 1991), is predicated on this assumption of the nonnegotiability of equivalence, the irreducibility of difference. And it is this which the concept of selling pigs throws into question. A pig is brought to an exchange not as a pig per se but as a particular pig. Its particular constellation of attributes, and its history, make it not only appropriate but, in a real sense, the only appropriate offering. Where pigs are sold, in contrast, attributes such as size, sex and colour may influence the going price but no longer bear upon the appropriateness of the particular pig to the intended transaction. A pig is suitable for sale simply because it is a pig. Thus it seems that the idea of 'pig' itself has been reified. The boundary between 'pig' as a category and other things has become more salient in guiding social action than the differences between particular pigs.

What has changed with the appearance of money is the notion of the irreducibility of differences between things. The earlier emphasis on equivalence in exchanges has been replaced by a recognition of substitutability. And as a result similarities have become, if not more salient than differences, then at least of increasing importance and categories, rather than individual identity, have become a basis for social action.

\section{THE REIFICATION OF GENDER}

By 1986-87 all adults at Gwaimasi spoke of themselves as being Christians aligned with the Evangelical Church of Papua New Guinea (ECPNG). This was the first mission to send Papua New Guinean pastors into the area and to establish missions, though the Seventh Day Adventist Church had been and was active at some more distant Kubo communities. No pastors lived at Gwaimasi at this time but the prevailing perception was that alignment with ECPNG would facilitate the appearance of airstrips, medical services, schools and stores that would stock axes, bush knives, cooking pots, clothing and so forth. Church services were sometimes held on Sundays and people prayed routinely before food was eaten at communal feasts and at times of minor crisis. But the influences of mission teaching were lightly felt. Christianity was accepted as an addition rather than an alternative to the expression of traditional beliefs and forms; seances, curing dances and initiations continued to be held and, of these, at least the last were not discouraged by the mission.

By 1995 the influence of Christianity was much stronger but was also more confused. There was a mood of disenchantment with ECPNG because it was apparent that this mission was unlikely to build an airstrip or send European missionaries to live at Gwaimasi and was not acting to replace the one pastor who three years earlier had spent some time based at the village. People said that ECPNG was 'not strong' and were turning, instead, to a new Christian cult. This cult, which since late 1994 has been growing in influence through the area, had its origins in the highlands as a derivative of the Christian Brethren Church (CBC) 
and in fact promoted itself as being that church. $\mathrm{CBC}$ had established a mission among a community of Febi people to the northeast of Gwaimasi through the mid 1980s, and its message (somewhat modified in form) subsequently spread west and south to Kubo, carried by highlanders purporting to be deacons of the church. One Febi man, in particular, from a community one day's walk north of Gwaimasi, was instrumental in carrying the teachings of the cult to Gwaimasi. A combination of seniority, charisma, strong affinal connections with Kubo speakers and a claim to be a deacon contributed to his perceived authority and to his success. But, further, when he visited Gwaimasi he organized lengthy night-time gatherings that combined instruction, prayer and hymn in a format that replicated traditional seances. He generated a mood of anxiety with frequent declarations that he himself had very recently encountered life-endangering spirit warriors (hugai) near the village and that the world would end in the year 2000 and raised expectations by reporting signs of the imminent return of Jesus. CBC does not approve of dancing or other customary ritual expression (nor, indeed, of the theatrical performances and games encouraged in ritual celebrations by ECPNG), but the subtle appropriation of traditional forms to convey a new message undoubtedly enhanced its appeal.

When we arrived at Gwaimasi in August 1995 people had built the frame and thatched the roof of their planned new church. It was intended that the church would be completed and formally opened toward the close of the year. At that time people spoke of the church as being associated with ECPNG but through the following months, after a succession of visits from Febi men, some conflict emerged regarding this affiliation. Church services, which were not yet held in the new building, became increasingly frequent and sometimes, at their close, were followed by meetings at which plans were developed for the forthcoming intercommunity gathering.

And through this time, largely under the guidance of the self-appointed cult leader, women were increasingly set apart from men during the services. They were encouraged to cover their heads and to sit with downcast eyes; there was the suggestion, though it was only partially taken up, that they should also cover their heads throughout Sunday and even on other days as well. The new church had separate doors for men and women and there was to be no mingling once people had entered. This was a religion for men. Only they could become wasman (baptised), stand behind the altar and read and comment on the bible $^{9}$. The explicit rationale drew on Eve as original sinner. Women had caused the downfall of men and only the latter could undo that harm. Women were to be the passive recipients of this knowledge and, to this end, required both public and private instruction. During his visits to Gwaimasi the cult leader provided that instruction in meetings with groups of women and sometimes in lengthy private sessions with particular married women. Nothing analogous to those cloistered meetings had previously been part of the public experience of Kubo; they would not have been acceptable. At Gwaimasi people declared that the authoritative certainty of cult messages and 'laws' demonstrated that, relative to ECPNG, the CBC mission was 'strong' 10 .

In December 1995 more than 100 people gathered at Gwaimasi to open the church and hold a celebratory feast. For three days before the formal ceremonies there were numerous services and a growing tension as people debated the allegiance of the Gwaimasi congregation to ECPNG or the cult. The official opening service was a compromise in including preachers and combining elements from both missions. But the structure within which that service was embedded was determined by members of the cult. The prominent 
role assumed by several Febi visitors diffused a reading of the event as being hosted by Gwaimasi. Neither the night before nor the night after the opening did people assemble at a traditional dance, and there were to be no plays or games. At the opening itself, only men senior members of ECPNG and baptised members of the cult - comprised the official welcoming party and women, nearly all with heads covered, entered the church grounds in an orderly line behind the men. Families were invisible.

The impact of the CBC-aligned cult at Gwaimasi has been to impose a structural separation of men and women, rationalized on the basis of biblical interpretations. That separation is predicated on subsuming social identity - as sister, wife or mother - within overarching categories of male and female. Difference - individuality itself - is subsumed and the categories male and female are being reified as a basis for structuring social action. The contrast with customary modes of expression that we observed nine years earlier at Gwaimasi and that obtained through much of southwest Papua is profound. Thus among Bedamuni, who are neighbours to Kubo, "'Male' and 'female' are in basic opposition at the cultural level but at the social level this dichotomy finds limited expression" and, more generally throughout this region, "the existence of a highly elaborate sexual dichotomy ... appears, however, to lose overwhelming significance in the social relations of men and women" (Feil 1987:183; see also Kelly 1993; Sørum 1984). At Gwaimasi, that symbolic dichotomy has become real ${ }^{11}$.

\section{OVERVIEW}

Kubo people and their neighbours remain relatively isolated from the sorts of impacts that have transformed social life through much of Papua New Guinea. With the exception of intermittent visits from mining exploration companies these people are untouched by major capitalist developments and they have had less than 10 years direct exposure to missionaries, primary schools and medical services. Indeed, by 1995, the continued presence of all the last was in doubt. Gwaimasi is itself relatively distant from these impacts and the people who live there are necessarily committed to a subsistence lifestyle. There are no cash crops and the desire to include rice and tinned fish on the menu can be seldom satisfied except as a now expected addition to feasts. Modernity, however, intrudes upon people's lives in subtle ways and Gwaimasi affords opportunities to observe ways in which people respond to and incorporate new understandings of the world and the possibilities these engender. The changes we have reported have by no means run their course but in as much as they represent relatively early and unhurried accommodations to modernity so they permit analysis of those changes as adaptation or transformation.

The increase in the number of domestic pigs at Gwaimasi may be attributed in the first instance to a realization that pigs afforded opportunities, which were otherwise not available, to exert some control over access to money and the benefits this could bring. However, production of additional pigs entailed substantial costs that were expressed overtly in changes to management procedures and the effort entailed in keeping those pigs and, more subtly, in separating wives from their husbands, aggravating tensions in some marriages and reducing the extent of task-sharing among those who cared for pigs. The consequences of these responses ran deep. Men were more often implicated in the recruitment of pigs to the domestic population, women who had cared for pigs increasingly lost control over the disposal of them and pigs were more likely to be removed from the domain of customary transactions. But these changes represent no more than adjustments 
to the changing economics of pig production. Should the potential to procure money by sale of pigs be recognised as illusory then the numbers raised may well decline again. Management practices, and the concomitant patterns of association between husbands and wives, could revert to those seen before.

But there has been another, more critical change associated with the monetisation of pigs. Monetary exchanges are predicated on a recognition that differences are commensurable. The associated shift in emphasis from equivalence to substitutability as a basis for exchange has undermined the priority of individual identity as the basis for social action.

The monetisation of pigs, the increasing separation of men and women that resulted and the reification of categories at the expense of individuality were underway at Gwaimasi before exposure to the teachings and forms of behaviour of the $\mathrm{CBC}$-aligned cult. That cult lent the authority of 'law' to changes already in train. In doing, so, however, the character of those changes was altered. The quantitative separation of men and women was simply a necessary adjustment - though not the only possible adjustment - in response to shifts in the system of pig production, a potentially reversible concomitant of the reproduction of form in altered circumstances. With the arrival of the cult, however, that adjustment was connected to new understandings of the world with the outcome that relationships that structure social action were themselves altered.

It is here, therefore, that we may separate components from a suite of interconnected variables as adaptive or transformative respectively. Changes that arise as the concomitants of the reproduction of form in altered circumstances are adaptive. Changes that entail irreversible alteration to expressions of social action, and thereby reshape the connections between form and circumstance, qualify as transformative. An understanding of the causes of evolution requires that we identify different categories of change, give each its due and understand the manner in which they interact to either elicit or inhibit further change.

\section{NOTES}

1. We acknowledge the historical baggage that adheres to the terms 'adaptation' and 'transformation'. We are aware also that biological and social scientists may have different opinions as to which term should be held in greatest contempt. Many biological scientists are satisfied that all or nearly all change conforms to what we have labelled 'adaptation'. They either rule 'transformation' out of court because it connotes 'internal forces' or they give it a nod, and dispense with it as trivial, in allowing mutation as the only source of new variants and, ultimately, new forms. Many social scientists, by contrast, subsume all change under the label 'transformation' and, thereby, avoid unwanted, though logically unnecessary, genetic connotations of 'adaptation'. They write instead of the reproduction of form, but in ways that fail to acknowledge that this necessarily entails differential survival of variants and that, where contexts themselves vary, the outcome is neither more nor less than 'adaptation' as we have defined it.

2. In 1995 the extent of association for one couple was much greater than that of any other (see woman 10, Table 1). These people had married in 1992, their one child was often unwell and the woman, who was not Kubo and did not speak Kubo, was not content at 
Gwaimasi. During the survey period she and her husband spent much time at the community where her natal family lived and they commenced building a house there.

3. The association between women and the pigs in their care and the bond that developed between a carer and her pigs are closer and stronger at Gwaimasi than reported from other low and middle altitude societies of New Guinea. In those other societies pigs are in the company of their carers for no more than five months, not the 18 months usual at Gwaimasi, and management relies on bonding to familiar areas more than to particular carers (Dwyer 1993).

4. Between 1986-87 and 1995, as the pig population at Gwaimasi began to increase, people experimented with a different system of pig management in which about half the local domestic population was kept at a distant house in the care of one or two married couples who lived away from the village for long periods (Dwyer 1993). The pigs were likely to be visited only intermittently by owners, they were difficult to bond and often lost. The experiment was judged a failure and the practice abandoned.

5. One potential side-effect of the rearrangements in patterns of association between wives and husbands is worth recording. In 1995 woman 2 cared for more pigs than, and her movements were more restricted than those of, any other woman (Table 1); on several occasions her husband took his 10 year old daughter to accompany him when he went hunting or visited communities one or two days' walk away. A man from a neighbouring village, similarly, was sometimes accompanied by his oldest daughter, aged eight, when he visited Gwaimasi. In 1986-87 such experiences were restricted to young boys. To an extent, therefore, an increase in the separation of married women and men was associated with a breakdown in the gender differentiation of children's experiences.

6. In 1986-87 the contribution of protein from domestic pigs was less than 10 percent of the quantity derived from wild vertebrates (Dwyer 1993); in 1995 domestic pigs contributed even less protein to diet. In both periods meat from domestic pigs was eaten irregularly and in neither period was the disposal of domestic animals patterned by availability of meat from wild animals in general or wild pigs in particular.

7. This is not to imply that pigs have become merely a commodity for Kubo. (In fact, money itself is not just a commodity to these people, remaining very much identified with its source; people can identify each note and coin they hold, detailing from whom, and in what context, it was received.) When Kubo offer a pig for sale the transaction is far from anonymous; they are negotiating their relationship with the potential purchasers. It will not be forgotten that one contributed to, say, raising a child's school fees even though pork was provided in exchange (cf. Gewertz and Errington 1991).

8. It is the contribution of labour towards satisfying previously negotiated arrangements that invests domestic pigs with their value as exchange items (Dwyer and Minnegal 1992b). Wild pigs, not having been the object of such investment, do not carry same potential for negotiation of relationships. Even as meat, wild pigs are perceived as inferior to their domestic counterparts, being considerably leaner.

9. In Papua New Guinea wasman is commonly used to mean 'pastor' (i.e. 'watch man'). Kubo, however, interpret the word as 'wash man' and associate it with baptism.

10. It is our understanding that the Christian Brethren Church draws on the Bible to promote a view that cataclysmic events will occur at an unknown time in the future and, on 
the basis that man was created before woman and it was the latter who was gullible and deceived, to rationalize different roles for men and women in church activities. Some people within the church discourage traditional dancing and teach that women should wear some head covering during communion services but, in fact, we have been assured by a CBC missionary that there is no Church constitution and no rules of belief and practice other than those revealed by the Bible. Practices observed at Gwaimasi reach beyond those acknowledged by the Church and appear to represent accretions promoted by CBC pastors from the Highlands and some Febi males.

11. Jolly and Maclntyre (1989) draw attention to the conflicting messages about domesticity and conjugal relations that have been conveyed by Christian missions in the Pacific. Espoused ideals of harmonious relations and gender equality have been undermined by practice that devalues women's activities and contributions. In different ways 'as Christian ideas became entrenched' misunderstanding 'contributed to the collapse of ... indigenous patterns of segregation' (ibid: 14). Among Kubo it is customary patterns of strong association between husbands and wives that are eroding. The CBC messages that reach Kubo are certainly influenced by the understandings of highlanders with their customary emphasis on the segregation of men and women. In addition, however, in as much as alignment with the $C B C$ cult qualifies as 'protest' - as a response to growing dissatisfaction with perceived failures of modernity, including ECPNG - so we might expect attraction to models that appear opposed to customary practice. And in the Kubo case customary practice was characterized by an unusually high level of gender equality.

\section{ACKNOWLEDGMENTS}

Research was conducted during periods of leave granted to PD by The University of Queensland. Fieldwork in 1995 was funded by a grant from the Papua New Guinea Biological Foundation; analyses and preparation of the manuscript were supported by a grant from the Australian Research Council. We thank the National Research Institute for permission to conduct the research and the government of Papua New Guinea for visas. Tom and Vicki Covington and Reg Howard provided help and information on our way into and out of the field. The work would, of course, have been impossible without the enthusiasm and assistance of the people of Gwaimasi and their neighbours.

\section{REFERENCES}

DWYER, P.D. 1993. The Production and Disposal of Pigs by Kubo People of Papua New Guinea. Memoirs of the Queensland Museum, 33: 123-142.

1996. Boars, Barrows and Breeders: The Reproductive Status of Domestic Pig Populations in Mainland New Guinea. Journal of Anthropological Research, 52: 481-500.

DWYER, P.D. and M. MINNEGAL. 1991. Hunting in Lowland Tropical Rainforest: Towards a Model of Non-agricultural Subsistence. Human Ecology 19: 187-212.

1992a. Ecology and Community Dynamics of Kubo People in the Tropical Lowlands of Papua New Guinea. Human Ecology 20: 21-55.

1992b. Cassowaries, Chickens and Change: Animal Domestication by Kubo of Papua New Guinea. Journal of the Polynesian Society 101: 373-85.

1993. Are Kubo Hunters 'Showoffs'? Ethology and Sociobiology 14: 53-70. 
1994. Sago Palms and Variable Garden Yields: A Case Study from Papua New Guinea. Man and Culture in Oceania 10: 81-102.

FEIL, D. 1987. The Evolution of Highland Papua New Guinea Societies. Cambridge: Cambridge University Press.

GEWERTZ, D.B. and F. ERRINGTON. 1991. Twisted Histories, Altered Contexts. Cambridge: Cambridge University Press.

GODELIER, M. 1986. The Making of Great Men: Male Domination and Power Among the New Guinea Baruya. Cambridge: Cambridge University Press.

GODELIER, M. and M. STRATHERN (eds). 1991. Big Men and Great Men: Personifications of Power in Melanesia. Cambridge: Cambridge University Press.

GREGORY, C. 1982. Gifts and Commodities. London: Academic Press.

JOLLY, M. and M. MACINTYPRE (eds). 1989. Family and Gender in the Pacific: Domsetic Contradictions and the Colonial Impact. Cambridge University Press, Cambridge.

JORGENSEN, D. 1991. Big Men, Great Men and Women: Alternative Logics of Gender Difference. In M. Godelier and M. Strathern (eds), Big Men and Great Men: Personifications of Power in Melanesia, pp. 256-71. Cambridge: Cambridge University Press.

KELLY, R.C. 1988. Etoro Suidology: A Reassessment of the Pig's Role in the Prehistory and Comparative Ethnology of New Guinea. In J.F. Weiner (ed.), Mountain Papuans: Historical and Comparative Perspectives from New Guinea Fringe Highlands Societies, pp. 111-86. Ann Arbor: University of Michigan Press.

1993. Constructing Inequality: The Fabrication of a Hierarchy of Virtue Among the Etoro. Ann Arbor: University of Michigan Press.

KNAUFT, B.M. 1985. Ritual Form and Permutation in New Guinea: Implications of Symbolic Process for Socio-political Evolution. American Ethnologist 12: 321-40.

1987. Reconsidering Violence in Simple Human Societies: Homicide among the Gebusi of New Guinea. Current Anthropology 28: 457-500.

LEVINS, R. and R. LEWONTIN. 1985. The Dialectical Biologist. Harvard University Press, Cambridge.

MINNEGAL, M. and P.D. DWYER. 1995. Production of Fish at Gwaimasi Village, Western Province, Papua New Guinea. Science in New Guinea 21(1): 27-40.

MODJESKA, N. 1982. Production and Inequality: Perspectives from Central New Guinea. In A.J. Strathern (ed.), Inequality in New Guinea Highlands Societies, pp. 50-108. Cambridge: Cambridge University Press.

RAPPAPORT, R.A. 1968. Pigs for the Ancestors: Ritual in the Ecology of a New Guinea People. New Haven: Yale University Press.

RUBEL, P.G. and A. ROSMAN. 1978. Your Own Pigs You May not Eat: A Comparative Study of New Guinea Societies. Canberra: Australian National University Press.

SHAW, R.D. 1982. Samo Initiation: Its Context and Its Meaning. Journal of the Polynesian Society 91: 417-34. 
1986. The Bosavi Language Family. Pacific Linguistics, Series A 70: 45-76.

1990. Kandila: Samo Ceremonialism and Interpersonal Relationships. Ann Arbor: University of Michigan Press.

SøRUM, A. 1984. Growth and Decay: Bedamini Notions of Sexuality. In G.H. Herdt (ed.), Ritualized Homosexuality in Melanesia, pp. 318-36. Berkeley: University of California Press.

STRATHERN, A.J. (ed.). 1982. Inequality in New Guinea Highland Societies. Cambridge: Cambridge University Press. 


\section{University Library}

\section{- $\mathrm{M}$ IIN E R VA A gateway to Melbourne's research publications}

Minerva Access is the Institutional Repository of The University of Melbourne

Author/s:

Minnegal, M;Dwyer, PD

Title:

Women, pigs, god and evolution: Social and economic change among Kubo people of Papua New Guinea

Date:

1997-09-01

Citation:

Minnegal, M. \& Dwyer, P. D. (1997). Women, pigs, god and evolution: Social and economic change among Kubo people of Papua New Guinea. Oceania, 68 (1), pp.47-60. https:// doi.org/10.1002/j.1834-4461.1997.tb02641.x.

Persistent Link:

http://hdl.handle.net/11343/56364 